Original Research Article

\title{
Pattern and practice of self medication in students of health professional university in North India
}

\author{
Shweta Singla, Mandeep Kaur*, Rajiv Mahajan
}

Department of Pharmacology, Adesh Institute of Medical

Sciences and Research,

Bathinda, Punjab, India

Received: 21 August 2017

Accepted: 21 September 2017

*Correspondence to:

Dr. Mandeep Kaur,

Email: mandeeplobana1 @

yahoo.com

Copyright: (C) the author(s), publisher and licensee Medip Academy. This is an openaccess article distributed under the terms of the Creative Commons Attribution NonCommercial License, which permits unrestricted noncommercial use, distribution, and reproduction in any medium, provided the original work is properly cited.

\begin{abstract}
Background: To determine the prevalence, pattern and practice of selfmedication in health professional students of a University in North India.

Methods: This cross sectional study was conducted over a period of 6 months among the students of University. Data was collected through anonymous, selfadministered, structured and validated 15 questions based questionnaire. Data was analysed by using descriptive statistical analysis.

Results: Out of the 1538 students enrolled, 1350 (88.6\%) students of University practiced self medication in the past 6 months. Prevalence of self medication varied among students of different courses (MBBS, BDS, Nursing, Physiotherapy, Pharmacy and paramedical) and different professional years of same course. Self medication practices were comparable between MBBS and BDS students with no significant difference $(\mathrm{p}=0.293)$. Fever and headache were the most frequently reported illness for which self medication was taken. Analgesics and antipyretics were the frequently self medicated drugs. Most common reason for seeking self medication was minor illness (41\%). Among all the students $6 \%$ of them complained of adverse effects with the use of self medication. About $85 \%$ students of University reported as treated with self medication.

Conclusions: Practice of self-medication is common among the health professional students. In this situation it is important to create awareness and educate the students about pros and cons of self medication through educational programs.
\end{abstract}

Keywords: Cross sectional study, Health care providers, University students

\section{INTRODUCTION}

Desire to take medicine is perhaps the key factor for the practice of self medication. World Health Organization (WHO) defines "self medication as the use of drugs to treat self diagnosed disorders or symptoms or the intermittent or continued use of prescribed drugs for chronic or recurrent disease or symptoms." Prevalence in developing countries widely varies between $12.7 \%$ to $95 \%$. In India the prevalence of self medication was $31 \%$ and $71 \%$ in studies conducted in Nagpur and Karnataka respectively. ${ }^{1}$ Self medication includes acquiring medicines without a prescription, resubmitting old prescriptions to purchase medicines, sharing medicines with relatives or members of one's social circle or using leftover medicines stored at home. $^{2}$ It also includes the use of medication for family members, especially where treatment of children or elderly is involved. ${ }^{3}$

In developing countries like India, self-medication is a common practice because of high cost of clinical services and easy alternatives available like drug retail shops which can be first point of contact for the patient population. ${ }^{4}$ Pharmacists and pharmacy attendants also play an important role in fostering self-medication among the public. ${ }^{5}$ Even WHO is promoting the practice of selfmedication for effective and quick relief of symptoms so 
that burden on health care services is reduced. ${ }^{5}$ But irrational use of drugs without authentic medical information can cause wastage of resources, increased resistance of pathogens, and can lead to serious health hazards such as adverse drug reaction and prolonged morbidity. ${ }^{6}$

This practice of self-medication is very common among the health professional students who are more exposed to the knowledge of different drugs during their training period as compared to general population. The studies have reported high prevalence ranging from $57.7 \%$ to $76 \% .^{3} \mathrm{~A}$ number of studies have been conducted to study the self-medication among medical students but pattern of self-medication remained unexplored on overall health care providers that includes dental, nursing, physiotherapy, pharmacy and paramedical students. Keeping this in view this questionnaire based study was planned to find out the prevalence, pattern and practice of self medication in health professional students of a University in North India.

\section{METHODS}

A cross-sectional study was done over a period of 6 months from October 2015 to March 2016 in a Health Professional University, in North India. Data was collected through self-administered, anonymous, structured, validated 15 questions based questionnaire which was filled up by students after obtaining informed consent and explaining about the aim of study and giving assurance about confidentiality of all information. Data were analyzed for those students who had self medicated within 6 months of recall period. The questionnaire included questions pertaining to demographic details, professional year of the course, indications for self-medication, details of type and pattern of drug usage, sources of drug information used, reasons favouring self-medication, awareness and knowledge of adverse effects of the drugs used. For the purpose of study, self-medication is defined as use of any pharmaceutical or medicinal products to treat self-recognized disorders or symptoms in the previous 6 months.

Study was initiated after getting approval from Institutional Research Committee (Ref. letter no: AIMSR/MC/Estt/05/2015/613). Thereafter permission was obtained from the Institutional Ethics Committee for the purpose of study.

\section{Statistical analysis}

The prevalence of self medication was reported as percentages. The survey was descriptive and data was summarized as counts and percentages, some of the questions had multiple options to choose from, therefore the sum total of percentage is not always $100 \%$. Unpaired t-test was used for comparing self medication practices among MBBS and BDS courses. Statistical analysis was done using Graph Pad Prism-version-5.03.

\section{RESULTS}

A total of 1538 students participated in the study, out of which 15 were excluded because of incomplete information. Remaining 1523 students questionnaire were considered for evaluation. Distribution of students according to different courses was: 771 from MBBS (students of $2^{\text {nd }}$ professional year includes from both $3^{\text {rd }}$ and $5^{\text {th }}$ semester), 290 from BDS, 254 from Nursing, 152 from Pharmacy, 37 from Physiotherapy and 18 students from Paramedical sciences. Mean age of the students was $20.39 \pm 1.69$ years. Out of 1523 students, 1037 (68\%) were females and $486(32 \%)$ were males.

Among 1523 students, $1350(88.6 \%)$ students of the university practiced self medication in the past 6 months. The prevalence of self medication varied amongst different courses and different professional years of the same course in the students of university as depicted (Table 1 and 2).

Table 1: Course wise distribution of study participants.

\begin{tabular}{|c|c|c|}
\hline $\begin{array}{l}\text { Course total p } \\
\text { self medication }\end{array}$ & & pants prac \\
\hline MBBS 77172 & & \\
\hline BDS & 290 & $249(85.8)$ \\
\hline Nursing & 254 & $211(83)$ \\
\hline Pharmacy & 152 & $130(85.5)$ \\
\hline Physiotherapy & 37 & $33(89.1)$ \\
\hline Paramedical & 18 & $16(88.8)$ \\
\hline
\end{tabular}

Table 2: Comparative analysis of self medication practices in MBBS and BDS students.

\begin{tabular}{|lllll|}
\hline $\begin{array}{l}\text { Professional } \\
\text { year of study }\end{array}$ & $\begin{array}{l}\text { Total Participants } \\
\text { (n) }\end{array}$ & $\begin{array}{l}\text { Participants practising } \\
\text { self medication, n (\%) }\end{array}$ & $\begin{array}{l}\text { Total } \\
\text { Participants (n) }\end{array}$ & $\begin{array}{l}\text { Participants practising self } \\
\text { medication, n }(\%)\end{array}$ \\
\hline I & 129 & $114(88 \%)$ & 65 & $51(78 \%)$ \\
\hline II & 298 & $289(97 \%)$ & 41 & $40(97 \%)$ \\
\hline III & 144 & $140(97 \%)$ & 78 & $69(88 \%)$ \\
\hline IV & 125 & $110(88 \%)$ & 87 & $83(95 \%)$ \\
\hline Interns & 75 & $68(90 \%)$ & 19 & $13(68 \%)$ \\
\hline
\end{tabular}


Self medication practices were comparable between MBBS and BDS students with no significant difference $(\mathrm{p}=0.293)($ Table 2$)$.

Fever and headache were the most frequently reported illness followed by cough and cold for which self medication was practiced. (Figure 1) Out of the various drugs employed for self medication, most commonly used were analgesics and antipyretics, followed by antibiotics. Amongst the drugs used Paracetamol, Diclofenac and Cetrizine were the most frequently used.

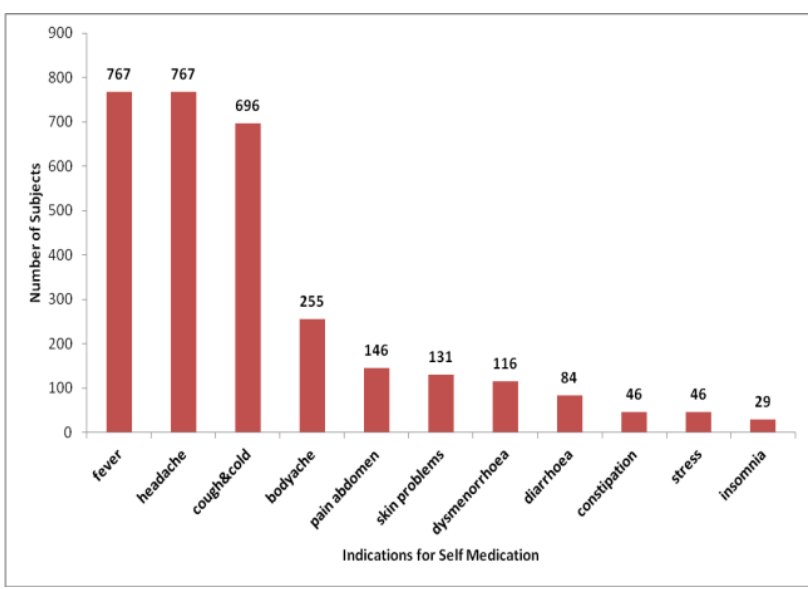

Figure 1: Indications for self medication.

With respect to source of information for self medication we observed that respondents got information about drugs from relatives and parents who are doctors $(30 \%)$ followed by text books, reading material $(26 \%)$ and friends $(19 \%)$.

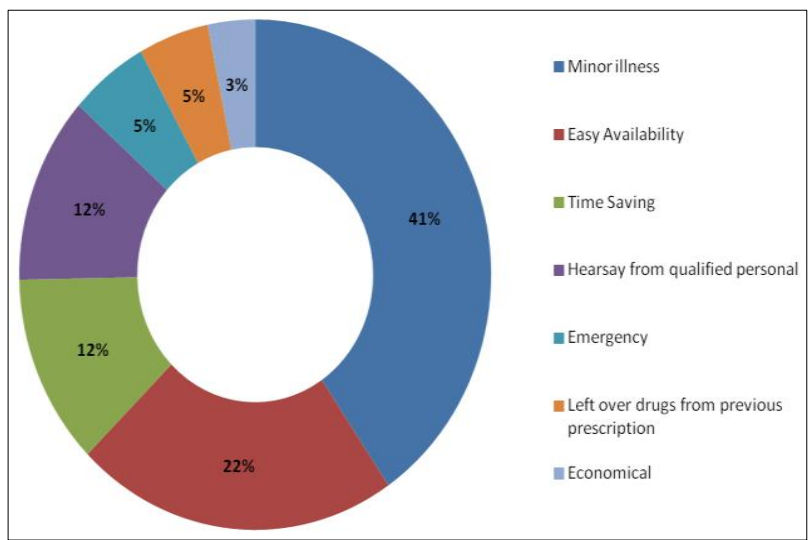

Figure 2: Reasons for self medication.

Figure 2 depicts the various reasons quoted for self medication among which no need to visit the doctor for minor illness $(41 \%)$ followed by easy availability of drug (22\%) were most common.

Most of the students were aware of the non-prescription medicines dose and duration of the drugs, drug interactions and adverse effects (Table 3). Among all the students $6 \%$ of them complained of adverse effects with the use of self medication and most commonly reported adverse effect was sedation (25\%) followed by GI upset in the form of diarrhoea or constipation.

Table 3: Awareness about self medication.

\begin{tabular}{|lllll|}
\hline Variables & $\begin{array}{l}\text { MBBS } \\
(\mathbf{7 7 1})\end{array}$ & $\begin{array}{l}\text { BDS } \\
(\mathbf{2 9 0})\end{array}$ & $\begin{array}{l}\text { Nursing } \\
(\mathbf{2 5 4})\end{array}$ & $\begin{array}{l}\text { Pharmacy } \\
(\mathbf{1 5 2})\end{array}$ \\
\hline $\begin{array}{l}\text { Dose and } \\
\text { duration }\end{array}$ & $\begin{array}{l}626 \\
(81 \%)\end{array}$ & $\begin{array}{l}218 \\
(75 \%)\end{array}$ & $\begin{array}{l}171 \\
(67 \%)\end{array}$ & $\begin{array}{l}103 \\
(67.7 \%)\end{array}$ \\
\hline Precautions & $\begin{array}{l}543 \\
(70.4 \%)\end{array}$ & $\begin{array}{l}204 \\
(70 \%)\end{array}$ & $\begin{array}{l}173 \\
(68 \%)\end{array}$ & $105(69 \%)$ \\
\hline $\begin{array}{l}\text { Drug } \\
\text { Interactions }\end{array}$ & $\begin{array}{l}326 \\
(42.2 \%)\end{array}$ & $\begin{array}{l}137 \\
(47 \%)\end{array}$ & $\begin{array}{l}105 \\
(41 \%)\end{array}$ & $61(40 \%)$ \\
\hline $\begin{array}{l}\text { Adverse } \\
\text { effects }\end{array}$ & $\begin{array}{l}496 \\
(64.3 \%)\end{array}$ & $\begin{array}{l}173 \\
(59.6 \%)\end{array}$ & $\begin{array}{l}112 \\
(44 \%)\end{array}$ & $68(44.7 \%)$ \\
\hline $\begin{array}{l}\text { Experience } \\
\text { ADR's }\end{array}$ & $\begin{array}{l}50 \\
(6.4 \%)\end{array}$ & $12(4 \%)$ & $\begin{array}{l}12 \\
(4.7 \%)\end{array}$ & $5(3.2 \%)$ \\
\hline
\end{tabular}

In context to the response to self medication, $85 \%$ of the students of the university reported as treated with self medication while rest of them reported as not treated or needed further consultation (Table 4). About 57\% students opined in favour of self medication for minor illness like fever, headache and cough or cold for future use.

Table 4: Primary outcome of self medication.

\begin{tabular}{|llll|}
\hline Courses & Treated & $\begin{array}{l}\text { Not } \\
\text { treated }\end{array}$ & $\begin{array}{l}\text { Needed } \\
\text { further } \\
\text { consultation }\end{array}$ \\
\hline MBBS & $89 \%$ & $0.1 \%$ & $3.6 \%$ \\
\hline BDS & $77 \%$ & $3.4 \%$ & $6.5 \%$ \\
\hline Nursing & $90 \%$ & $2 \%$ & $2.3 \%$ \\
\hline Pharmacy & $81 \%$ & $1.3 \%$ & $3.2 \%$ \\
\hline Physiotherapy & $78.3 \%$ & $8.1 \%$ & $5.4 \%$ \\
\hline Paramedical & $94.4 \%$ & $5.5 \%$ & 0 \\
\hline
\end{tabular}

\section{DISCUSSION}

The practice of self-medication is widespread all over the world especially in urban and educated population. Frequency of self-reported medication is highly variable in different parts of the world; as low as $45 \%$ in Turkey to as high as $94 \%$ in Hong Kong. ${ }^{2}$ This variation to report selfmedication may be due to the differences in study subjects, working definition of self-medication and tool used to collect the response of the participants.

Present study reported prevalence of self-medication among the University students of about $88 \%$ which is almost similar to the study conducted by Adhikari in Delhi University students $(85.4 \%){ }^{2}$ Our study population consisted of students of different courses like MBBS, BDS, Nursing, Pharmacy, Physiotherapy and paramedical sciences. Health care providers acquire knowledge of drugs and skills of drug selection and prescribing during the undergraduate training which includes internship. They start relying on self medication during their formative years of undergraduate training. In our 
University setup, 93.5\% MBBS students practiced self medication which is almost similar to the prevalence $(82 \%)$ reported by Pandya in his study conducted in Ahmedabad. ${ }^{3}$ A low prevalence of $57.05 \%$ by Banerjee in West Bengal and $53 \%$ by Nalini in Karnataka has also been seen. ${ }^{6,7}$

In the study conducted by Kalra in a dental college, Pune; $40.9 \%$ students practiced self medication. ${ }^{8}$ There is a considerable difference from our university dental students in whom the prevalence of self medication was reported in about $85 \%$ students. Not much data is available about the self-medication in nursing students. Study conducted by Goel in a medical college in Haryana, $88.24 \%$ nursing students has practiced self-medication which is almost similar to our study in which $90 \%$ of the nurses practiced the same. ${ }^{9}$

The common morbidities which prompted the students to practice self-medication were fever, headache followed by cough and cold and this is comparable to many earlier studies with only a negligible difference in context to the different courses in the University. ${ }^{2,10}$ Antipyretics, analgesics, antibiotics and cough syrups were the among the frequently used drugs for self medication in the present study. In the study conducted by Zafar in Karachi, analgesics were most common $(88.3 \%)$, followed by antipyretics and antibiotics whereas Banerjee reported use of antibiotics followed by analgesics and antipyretics. ${ }^{6,11}$

Reasons given in favor of self medication were comparable in all the studies and main reasons were no need to visit a doctor for minor illness, time saving, economical, convenient, etc. Results of the present study indicated that the most common reasons for selfmedication were minor ailments $(41 \%)$ and easy availability of drugs (22\%), which is similar to Pahuja and James study that reported the reasons as minor illness $(40 \%)$ and shortage of time to consult a doctor $(32 \%){ }^{12,13}$

Most of the students were aware of the dose and frequency of the drugs used for self medication, necessary precautions to be taken and drug interactions (Table 3). These findings were almost similar to a Kasulkar study conducted in Nagpur. ${ }^{14}$ Majority of the students irrespective of the year/ course of the study reported that they were aware of adverse effects of medicines used by them which are analogous with the findings of studies done by Patel and Kumari on medical students. ${ }^{15,16}$ In our study $6.4 \%$ of the students reported that they experienced adverse effects with self medication and most common was sedation and dizziness followed by GI upset and rashes.

Majority of students agreed that medical knowledge is necessary for administration of medicine by self which, is in accordance with other studies. In context to the response to self medication, $85 \%$ of the students of the university reported as treated with self medication which is nearly similar to a study conducted by Singh in a tertiary care medical college in which $89.4 \%$ reported relieved with the use of self medication. ${ }^{17}$ Others reported as not treated or needed further consultation (Table 4).

\section{CONCLUSION}

Our study shows that self medication is widely practiced among the students of University especially for minor illness and because of easy availability of drugs. The study was based on self reported data about self medication in the preceding 6 months. As responsible self-medication is now increasingly being considered as a component of selfcare, there is a need for review of educational programs especially teaching of rational and judicious use of medicines. It can help prevent and treat diseases that do not require medical consultation and provides a cheaper alternative for treating common illnesses. Self-medication by authentic medical information can prevent burden on the health care system in a country like India, where there is scarcity of health professionals.

\section{Funding: No funding sources \\ Conflict of interest: None declared}

Ethical approval: The study was approved by the Institutional Ethics Committee (Ref. no: AU/IEC/FM/44/2015)

\section{REFERENCES}

1. Chari HS, Kadeangadi DM, Mallapur MD. Practice of self medication among urban households- A community based cross sectional study. Ntl $\mathbf{J}$ of Community Med. 2015;6(2):93-6.

2. Adhikary M, Tiwari P, Singh S, Karoo C. Study of self-medication practices and its determinants among college students of Delhi university north campus, New Delhi, India. Int J Med Sci Public Health. 2014;3(4):406-9.

3. Pandya RN, Jhaveri KS, Vyas FI, Patel VJ. Prevalence, pattern and perceptions of self-medication in medical students. Int $\mathrm{J}$ Basic Clin Pharmacol. 2013;2(3):275-80.

4. Simon AK, Rao A, Rajesh G, Shenoy R, Pai MB. Trends in self-medication for dental conditions among patients attending oral health outreach programs in coastal Karnataka, India. Indian $\mathrm{J}$ Pharmacol. 2015;47:524-9.

5. IHS, SSK, Jayan M, Hussain A. Prevalence of self medication practices and its associated factors in rural Bengaluru, Karnataka, India. Int J Community Med Public Health. 2016;3(6):1481-6.

6. Banerjee I, Bhadury T. Self-medication practice among undergraduate medical students in a tertiary care medical college, West Bengal. J Postgrad Med. 2012;58:127-31.

7. Nalini GK. Self-medication among Allopathic medical doctors in Karnataka, India. BJMP. 2010;3:325.

8. Kalra DD, Kini PV, Kalra RD, Jathanna VR. Assessment of self-medication among dental students 
in Pune city, Maharashtra: A cross-sectional survey. J Indian Assoc Public Health Dent. 2015;13:318-23.

9. Goel D, Gupta S. Self-medication patterns among nursing students in North India. Journal of Dental and Medical Sciences. 2013;11(4):14-7.

10. Thadani S, Tariq SM, Ahmad A. Knowledge, Attitude and Practice of Self medication Among Second Undergraduate Medical Students. J Rational Pharmacother Res. 2013;1(3):131-4.

11. Zafar SN, Reema S, Sana W, Akbar JZ, Talha V, Mahrine S, et al. Self-medication amongst university students of Karachi: Prevalence, knowledge and attitudes. J Pak Med Assoc. 2008;58:214-7.

12. Pahuja R, Singh H, Rohit M, Gupta G, Bhasin P. An online exploratory study of self medication among pharmacy graduates in India. Int. J. Drug Dev. \& Res. 2011;3(4):200-7.

13. James H, Handu SS, Al Khaja KA, Otoom S, Sequeira RP. Evaluation of the knowledge, attitude and practice of selfmedication among first-year medical students. Med Princ Pract. 2006;15:270-5.
14. Kasulkar A, Gupta M. Self Medication Practices among Medical Students of a Private Institute. Indian J Pharm Sci. 2015;77(2):178-82.

15. Patel PM, Prajapati AK, Ganguly B, Gajjar BM. Study on impact of Pharmacology teaching on knowledge, attitude and practice on self-medication among medical students. Int $\mathrm{J}$ Med Sci Public Health. 2013;2:181-6.

16. Kumari R, Kiran, Kumar D, Bahl R, Gupta R. Study of knowledge and practices of self-medication among medical students at Jammu. J Medical Sciences. 2012;15(2):141-4.

17. Singh G, Sidhu TK, Mahajan R. Pattern of selfmedication among Medical Students. J Res Medical Education \& Ethics. 2013;3(3):252-7.

Cite this article as: Singla S, Kaur M, Mahajan R. Pattern and practice of self medication in students of health professional university in North India. Int $\mathbf{J}$ Basic Clin Pharmacol 2017;6:2607-11. 